\title{
Hepatitis C: Recent advances
}

$\mathrm{S}$ INCE THE INITIAL PUBLICATION OF THE DISCOVERY OF HEPAtitis C virus (HCV) by Choo et al (1) from Chiron Corporation in April 1989, much has been learned about the biology, epidemiology and clinical features of $\mathrm{HCV}$ infection. In this edition of the notes, we highlight some of the more recent findings.

Better serological testing: Second generation serological tests are now in use. The second generation enzyme immunoassay (EIA) is more sensitive than the first generation assay (2). Furthermore, the second generation recombinant immunoblot assay (RIBA), used by many laboratories as a confirmatory test for HCV infection, is more specific than earlier assays $(2,3)$. Although the second generation tests permit earlier detection of $\mathrm{HCV}$ antibody than first generation tests, the diagnosis of HCV infection can seldom be made serologically in the first six weeks following infection.

Finally, the previous speculation that the high rate of HCV seropositivity when tested by EIA seen in autoimmune chronic hepatitis (4) is spurious has been confirmed by the absence of HCV RNA in such patients (5).

Screening of blood donors: There is now conclusive evidence that excluding blood donated by individuals who test HCV-seropositive substantially reduces the incidence of post-transfusional non-A, non-B hepatitis to a greater extent than the use of serum alanine aminotransferase (ALT) and hepatitis B surface antigen antibody as surrogate markers (6).

Transmission: The most established route of transmission of $\mathrm{HCV}$ is parenteral, with high rates of infection in injection drug users and recipients of large quantities of blood products, such as hemophiliacs. Consistent with this route of transmission, occupational HCV infection of health care workers via needlestick injuries is well documented $(7,8)$, and likely accounts for the higher rate of $\mathrm{HCV}$-seropositivity reported in dentists, compared with controls (9). The risk of HCV infection with a single needlestick injury has been reported at $4 \%$ in one study (7) and 10\% in another (8); thus the risk is intermediate between that of human immunodeficiency virus at approximately $0.3 \%$ and hepatitis $\mathrm{B}$ virus (HBV) at 20 to $40 \%$.

Transmission via organ transplantation has also been documented with high rates of transmission reported in two studies $(10,11)$, and a low rate of transmission reported in another (12). Given the limited supply of organs for transplantation, some programs permit the transplantation of organs other than the liver from $\mathrm{HCV}$-seropositive donors into recipients who are already HCV-seropositive. Sexual (13) and vertical (14) transmission of HCV remain infrequent but both clearly occur. Of note, the route of transmission remains unknown in about $40 \%$ of cases (15), a proportion comparable to that for HBV.

HCV RNA: Since the report of the initial polymerase chain reaction (PCR) assay for HCV RNA by Weiner et al (16) from Chiron, many research laboratories now perform this assay. However, the significant interlaboratory variability of this assay suggests that standardization and proficiency testing will be required (17).

Several investigators have developed quantitative assays for HCV RNA. A particularly promising quantitative assay is the novel technique of branched DNA signal amplification (18), which has recently been assessed clinically (19).

HCV RNA assays offer the potential of earlier diagnosis and high specificity where serology is equivocal. Quantitative assays are now essential in clinical trials assessing antiviral therapy (20).

Essential mixed cryoglobulinemia (EMC): EMC is a relatively rare condition characterized by purpura, arthralgia and weakness, often together with glomerulo- 
nephritis. The diagnosis of EMC requires the demonstration of serum cryoglobulins made up of polyclonal immunoglobulin (Ig) G and monoclonal IgM rheumatoid factors.

Several groups of investigators have demonstrated a high prevalence of HCV seropositivity in patients with EMC $(21,22)$, with concentration of both HCV RNA and anti-HCV in the cryoprecipitate $(22,23)$. Some of these patients also have membranoproliferative glomerulonephritis (23).

HCV in liver disease: Recent studies indicate that a majority of $\mathrm{HCV}$-seropositive individuals have liver disease, despite the fact that most are asymptomatic (24). Normal serum aminotransferase levels do not exclude the presence of chronic hepatitis (25). Furthermore, whereas individuals with chronic hepatitis usually have detectable HCV RNA in serum, circulating HCV RNA may remain detectable for several years in the absence of liver disease (26). Thus, the assessment of asymptomatic $\mathrm{HCV}$-infected individuals with persistently normal serum aminotransferases has become confusing, and arguments can be made for and against peforming a liver biopsy in such individuals, largely influenced by one's belief regarding the efficacy of treatment.

Treatment of HCV: Currently, the only approved treatment for chronic HCV infection is with interferon-alpha. However, interferon-alpha is expensive, toxic and has limited efficacy. No more than $50 \%$ of patients experience improvement with this therapy and relapses are very common $(27,28)$. Unfortunately, as with recent antiretroviral drugs, interferon-alpha was licensed for the treatment of $\mathrm{HCV}$ on the basis of surrogate data, ie, improvement in ALT, rather than convincing data demonstrating either a sustained antiviral effect or long term clinical benefits. Thus, it remains to be determined whether interferon-alpha prevents the development of cirrhosis or hepatocellular carcinoma. Furthermore, a recent study indicates that individuals who are followed an average of 18 years after developing transfusionassociated non-A, non-B hepatitis have no increase in

\section{REFERENCES}

1. Choo Q-L, Kuo G, Weiner AJ, Overby LR, Bradley DW, Houghton $\mathrm{M}$. Isolation of a cDNA clone derived from a bloodborne non-A, non-B hepatitis genome. Science 1989:244:359-62.

2. Aach RD, Stevens CE, Hollinger FB, et al. Hepatitis C virus infection in post-transfusion hepatitis. An analysis with first- and second-generation asays. N Engl J Med 1991;325:1325-9.

3. Van Der Poel CL, Cuypers HTM, Reesink HW, et al. Confirmation of hepatitis $\mathrm{C}$ virus infection by new four-antigen recombinant immunoblot assay. Lancet 1991;337:317-9.

4. Lenzi M, Ballardini G, Fusconi M, et al. Type 2 autoimmune hepatitis and hepatitis $\mathrm{C}$ virus infection. Lancet 1990;335:258-9.

5. Nishiguchi S, Kuroki T, Ueda T, et al. Detection of hepatitis C virus antibody in the absence of viral RNA in patients with autoimmune hepatitis. Ann Intern Med 1992;116:21-5. mortality from all causes, compared with two control groups (29). There was a small, statistically significant increase in deaths related to liver disease, but $71 \%$ of these occurred in chronic alcoholics (29). Therefore, the potential for an effective HCV therapy to reduce mortality is limited. Until placebo controlled trials demonstrate that inteferon-alpha results in a sustained clearance of HCV RNA from serum in a substantial proportion of patients and/or reduced progression to cirrhosis and/or hepatocellular carcinoma, its use in HCV must still be considered experimental (30).

Oral ribavirin has also been evaluated in the treatment of chronic HCV infection in two open-label pilot studies $(31,32)$. In both studies, nearly all patients experienced a significant fall in serum ALT, and the drug was well tolerated. Furthermore, a fall in quantitative HCV RNA was observed (32), although HCV RNA did not disappear completely. Unfortunately, virtually all patients relapsed following discontinuation of therapy $(31,32)$. In contrast, some patients treated with interferon-alpha achieve sustained virological remissions with undetectable HCV RNA over a period of several years (33).

Prospect for vaccine: Although about $50 \%$ of $\mathrm{HCV}$ infected individuals clear the virus spontaneously, the determinants of immunity in such individuals have not been defined. Furthermore, at least five HCV genotypes are now recognized (34), and it is unknown whether immunity to one type confers cross-immunity to one or more of the other genotypes.

Even more discouraging is the observation that chimpanzees inoculated with $\mathrm{HCV}$ who clear the virus do not develop protective immunity to repeat intravenous challenge with either homologous or heterologous HCV (35). Interestingly, chimpanzees who become chronically infected with HCV are resistant to superinfection with heterologous HCV (35). These data suggest that $\mathrm{HCV}$ vaccine development will be considerably more challenging than the development of vaccines for hepatitis A virus and hepatitis B virus.

6. Donahue JG, Munoz A, Ness PM, et al. The declining risk of post-transfusion hepatitis C virus infection. N Engl J Med 1992;327:369-73.

7. Kiyosawa K, Sodeyama T, Tanaka E, et al. Hepatitis C in hospital employees with needlestick injuries. Ann Intern Med 1991;115:367-9.

8. Mitsui T, Iwano K, Masuko K. et al. Hepatitis C virus infection in medical personnel after needlestick accident. Hepatology 1992;16:1109-14.

9. Klein RS, Freeman K, Taylor PE, Stevens CE. Occupational risk for hepatitis $\mathrm{C}$ virus infection among New York City dentists. Lancet 1991;338:1539-42.

10. Pereira BJG, Milford EL, Kirkman RL, Levey AS. Transmission of hepatitis $\mathrm{C}$ virus by organ transplantation. N Engl J Med 1991;325:454-60.

11. Pereira BJG, Milford EL, Kirkman RL, et al. Prevalence of hepatitis $\mathrm{C}$ virus RNA in organ donors positive for hepatitis $\mathrm{C}$ antibody and in the recipients of their organs. N Engl J Med 1992;327:910-5.

12. Roth D. Fernandez JA, Babischkin S, et al. Detection of hepatitis $\mathrm{C}$ virus infection among cadaver organ donors: 
Evidence for low transmission of disease. Ann Intern Med 1992;117:470-5.

13. Kao JH, Chen PJ, Yang PM, et al. Intrafamilial transmission of hepatitis $\mathrm{C}$ virus: The important role of infections between spouses. J Infect Dis 1992;166:900-3.

14. Wejstal R, Widell A, Mansson A-S, Hermodsson S, Norkrans G. Mother-to-infant transmission of hepatitis C virus. Ann Intern Med 1992;117:887-90.

15. Alter MJ, Hadler SC, Judson FN, et al. Risk factors for acute non-A, non-B hepatitis in the United States and association with hepatitis $C$ virus infection. JAMA 1990;264;2231-5.

16. Weiner AJ, Kuo G, Bradley W, et al. Detection of hepatitis $\mathrm{C}$ viral sequences in non- $\mathrm{A}$, non-B hepatitis. Lancet 1990;335:1-3.

17. Zaaijer HL, Cuypers HTM, Reesink HW, Winkel IN Gerken G, Lelie PN. Reliability of polymerase chain reaction for detection of hepatitis $\mathrm{C}$ virus. Lancet 1993:341:722-4.

18. Urdea MS, Horn T, Fultz TJ, et al. Branched DNA amplification multimers for the sensitive, direct detection of human hepatitis viruses. In: Nucleic Acids Research Symposium Series, no 24. Oxford: Oxford University Press, 1991:197-200.

19. Lau JYN, Davis GL, Kniffen J, et al. Significance of serum hepatitis C virus RNA levels in chronic hepatitis C. Lancet 1993;341:1501-4.

20. Kleter GEM, Brouwer JT, Heijtink RA, Schalm SW, Quint WGV. Detection of hepatitis C virus RNA in patients with chronic hepatitis $\mathrm{C}$ virus infections during and after therapy with alpha interferon. Antimicrob Agents Chemother 1993:37;695-7.

21. Misiani R, Bellavita P, Fenili D, et al. Hepatitis C virus infection in patients wth essential mixed cryoglobulinemia. Ann Intern Med 1992;117:573-7.

22. Agnello V, Chung RT, Kaplan LM. A role for hepatitis C virus infection in Type II cryoglobulinemia. N Engl J Med 1992:327:1490-5.

23. Johnson RJ, Gretch DR, Yamabe H, et al. Membranoproliferative glomerulonephritis associated with hepatitis $\mathrm{C}$ virus infection. $\mathrm{N}$ Engl $\mathrm{J}$ Med 1993:328:465-70.

24. Esteban JI, Lopez-Talavera JC, Genesca J, et al. High rate of infectivity and liver disease in blood donors with antibodies to hepatitis C virus. Ann Intern Med 1991;115:443-9.

25. Alberti A, Morsica G, Chemello L, et al. Hepatitis C viraemia and liver disease in symptom-free individuals with anti-HCV. Lancet 1992;340:697-8.

26. Brillanti S, Foli M, Gaiani S, Masci C, Miglioli M, Barbara L. Persistent hepatitis C viraemia without liver disease. Lancet 1993:341:464-5.

27. Davis GL, Balart LA, Schiff ER, et al. Treatment of chronic hepatitis $\mathrm{C}$ with recombinant interferon alfa. A multicenter randomized, controlled trial. N Engl J Med 1989:321:1501-6.

28. Di Bisceglie AM, Martin P, Kassianides C, et al. Recombinant interferon alfa therapy for chronic hepatitis C. A randomized, double-blind, placebo-controlled trial. N Engl J Med 1989;321:1506-10.

29. Seeff LB, Buskell-Bales Z, Wright EC, et al. Long-term mortality after transfusion-associated non-A, non-B hepatitis. N Engl J Med 1992;327:1906-11.

30. Koretz RL. Interferon and chronic non-A, non-B hepatitis: Whom are we treating? Hepatology 1990;12:613-5.

31. Reichard O, Andersson J, Schvarcz R, Weiland O. Ribavirin treatment for chronic hepatitis C. Lancet 1991;337: 1058-61.

32. Di Bisceglie AM, Shindo M, Fong T-L, et al. A pilot study of ribavirin therapy for chronic hepatitis C. Hepatology 1992: 16:649-54.

33. Shindo M, Di Bisceglie AM, Hoofnagle JH. Long-term follow-up of patients with chronic hepatitis $\mathrm{C}$ treated with $\alpha$-interferon. Hepatology 1992;15:1013-6.

34. Cha TA, Beall F, Irvine B, et al. At least five related, but distinct, hepatitis C viral genotypes exist. Proc Natl Acad Sci USA 1992;89:7144-8.

35. Farci P, Alter HJ, Govindarajan S, et al. Lack of protective immunity against reinfection with hepatitis $\mathrm{C}$ virus. Science $1992 ; 258: 135-40$ 


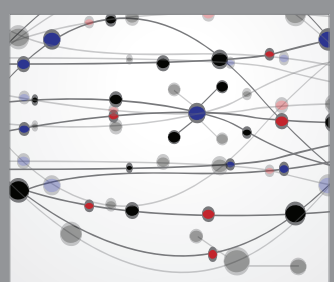

The Scientific World Journal
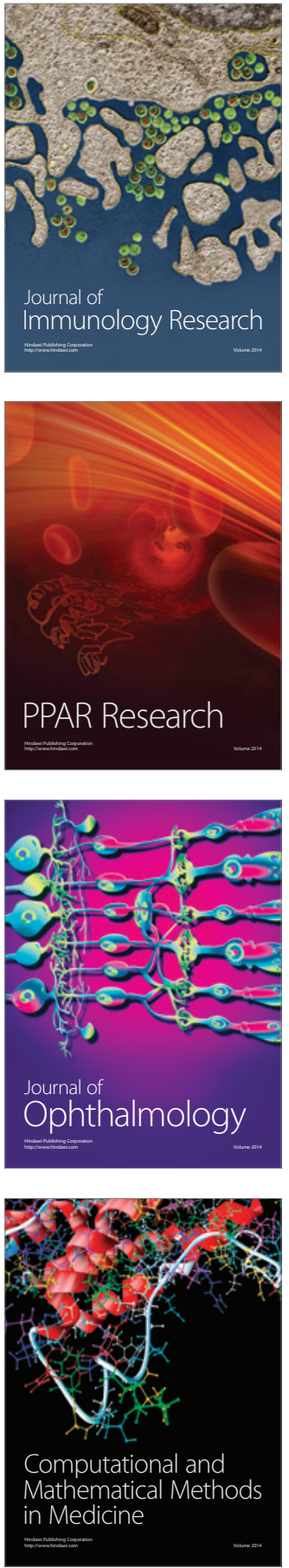

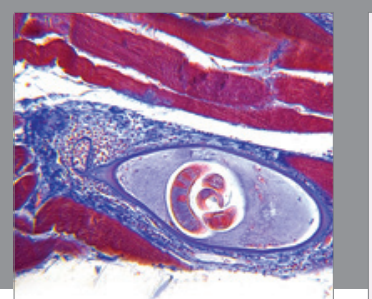

Gastroenterology Research and Practice

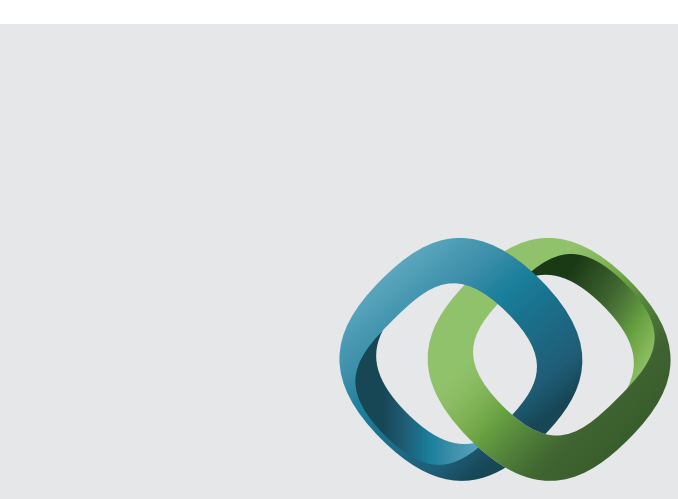

\section{Hindawi}

Submit your manuscripts at

http://www.hindawi.com
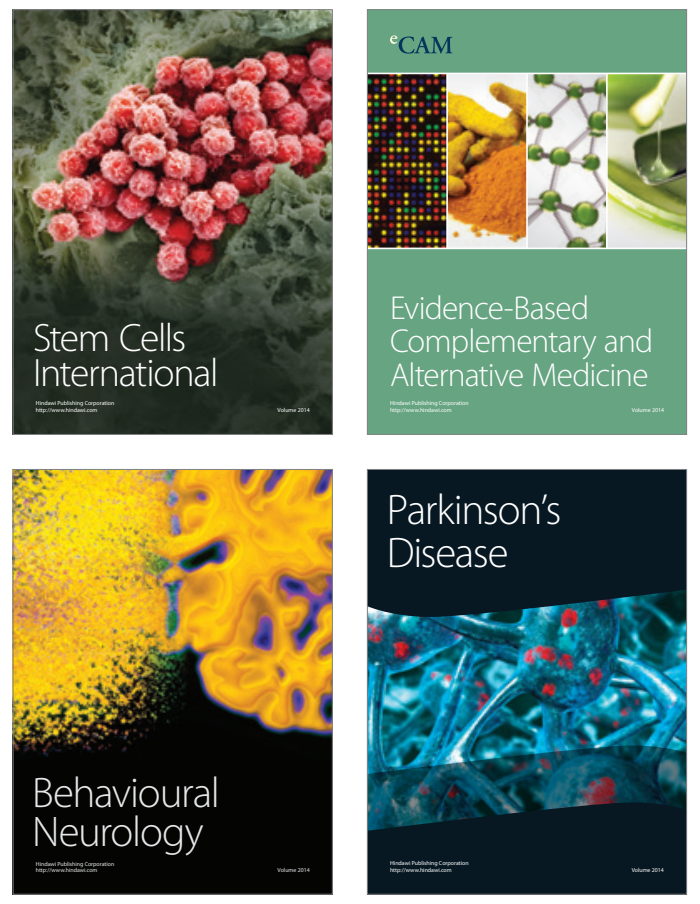
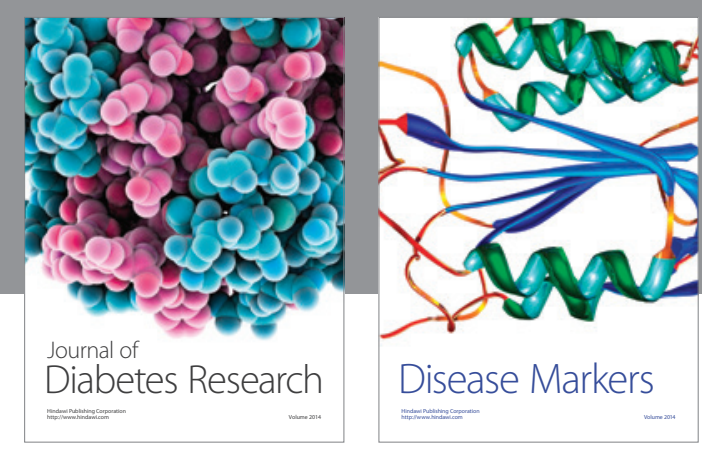

Disease Markers
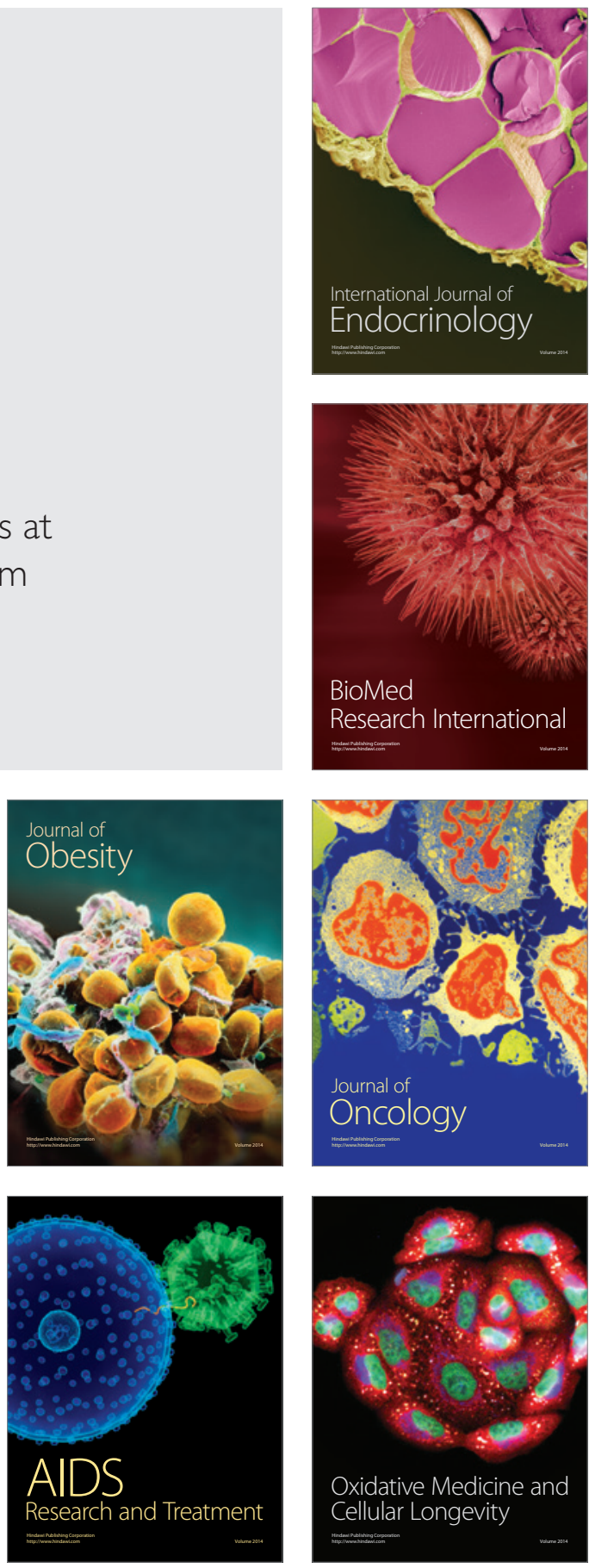